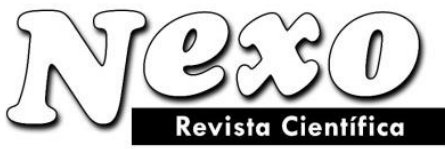

ISSN-E 1995-9516

Universidad Nacional de Ingeniería COPYRIGHT (C) (UNI). TODOS LOS DERECHOS RESERVADOS http://revistas.uni.edu.ni/index.php/Nexo https://doi.org/10.5377/nexo.v33i02.10790

\title{
Investigating the effective factors on employment-oriented empowerment of rural female heads of households in ilam, Irán
}

\section{Investigación de los factores efectivos sobre el empoderamiento orientado al empleo de las mujeres jefas de hogares rurales en Ilam, Irán}

\author{
Satar Naseri, Hamed Chaharsoughi Amin*, Alireza Poursaeed, Mohammad Bagher Arayesh \\ Department of Agricultural Extension and Education, Ilam Branch, Islamic Azad University, \\ Ilam, Iran.
}

*Corresponding author email: h_chaharsoughi@outlook.com

(recibido/received: 17-August-2020; aceptado/accepted: 19-September-2020)

\begin{abstract}
The purpose of this study is to investigate the factors affecting the employment-oriented empowerment of rural female heads of households in Ilam. In terms of monitoring and degree of control, this is field research and in terms of method of obtaining facts and data processing, it is a survey study and in terms of data collection, it is descriptive-correlational. The statistical population of this study is 14156 rural female heads of households in Ilam. The sample size was set for 374 people using Krejcie and Morgan Table. In this study, due to having a list of the names of all women studied, a systematic sampling method was used. The data collection tool in this study was a researcher-made questionnaire whose face validity and content validity were provided through a panel of experts. The reliability of the questionnaire was also confirmed by Cronbach's alpha. The results of regression analysis showed that the variables of psychological dimension, social dimension, cultural dimension, and the technical dimension of professional competencies have the greatest impact on the empowerment of rural women and in other words, explain $52 \%$ of the changes in the empowerment variable of women.
\end{abstract}

Keywords: Empowerment; Professional Competencies; Female Heads of Households; Ilam.

\section{RESUMEN}

El propósito de este estudio es investigar los factores que afectan el empoderamiento orientado al empleo de las mujeres jefas de hogar rurales en Ilam. En términos de seguimiento y grado de control, se trata de una investigación de campo y en términos de método de obtención de hechos y procesamiento de datos, es un estudio de encuesta y en términos de recolección de datos es descriptivo-correlacional. La población estadística de este estudio es 14156 mujeres jefas de hogar rurales en Ilam. El tamaño de la muestra se 
estableció para 374 personas utilizando Krejcie y Morgan Table. En este estudio, debido a tener una lista de los nombres de todas las mujeres estudiadas, se utilizó un método de muestreo sistemático. La herramienta de recolección de datos en este estudio fue un cuestionario elaborado por investigadores cuya validez aparente y validez de contenido fueron proporcionadas a través de un panel de expertos. La fiabilidad del cuestionario también fue confirmada por el alfa de Cronbach. Los resultados del análisis de regresión mostraron que las variables de dimensión psicológica, dimensión social, dimensión cultural y la dimensión técnica de las competencias profesionales tienen el mayor impacto en el empoderamiento de las mujeres rurales, es decir, explican el 52\% de los cambios en el empoderamiento. variable de mujeres.

Palabras clave: Empoderamiento; Competencias profesionales; Jefas de hogar; Ilam.

\section{INTRODUCTION}

Women make up about half of the country's population. However, only a small number of them are employed and earn a living. Statistics show that most women work at home and if they work, they are more likely to work in low-income jobs. Statistics announced by the Statistics Center of Iran in 2016 show that male unemployment this year was 10.3 and female unemployment was 20.3 (Statistical Yearbook, 2016). This can be a threat or a good opportunity for progress. The threat is that if this population remains unemployed, the country's economy will suffer a lot. In this sense, this issue can be an opportunity only if the country uses this large workforce, it will achieve very high economic growth. The only necessary condition for success and achievement of economic, political, cultural, and social goals has been the correct and optimal use of human resources and their thinking power, and one of the important indicators for measuring the development of any country is the employment status of women and their participation in different fields.

Employment is one of the indicators of national economy modernization and economic development. Although the economic necessity of women's employment and participation in economic activities has always been raised in the history of the progress and development of societies, in this regard, a favorable situation for women has not yet been created. One of the reasons is the lack of attention to women's education and the lack of a suitable platform for creating employment opportunities for them. This deprivation has severely degraded the socio-economic position of women in the process of sustainable development (Papzan et al., 2011). In this regard, female heads of households are in a much worse situation than other women. The poor economic situation has made both female heads of households and their children among the most vulnerable in society to social ills. Increasing the roles of female heads of households in the absence of a spouse creates problems in economic, social, physical, psychological, legal, and family issues for them that can affect their quality of life in all aspects (Boldaji et al., 2011). A study of the lives of female-headed households in urban areas of Ilam showed that about $64.44 \%$ of female heads of households in this province live alone with their children, which had the highest number of female-headed households among the provinces in 2011 (Eftekhari et al., 2013).

Psychologists believe that female heads of households have problems both materially and psychologically and emotionally and experience more stress and anxiety. According to psychological research, women who are divorced and are the heads of the household too are much more likely to develop mental illness than married people or those who live alone (Connell \& Brazier, 2012). Therefore, one of the important approaches is to pay attention to women's society, especially the women who are the heads of households and empower them. Empowerment means increasing the abilities of the people being supported in such a way that they can best do their desired profession and succeed in it. In the Fifth Development Plan, one of the most important tasks assigned to support organizations is empowerment. Article 95 of the Constitution also emphasizes "defining the poverty line and explaining appropriate empowerment programs" and "designing special employment programs" to reduce poverty and deprivation and establish justice. 
Therefore, the main question of the present study is what are the factors affecting the employmentoriented empowerment of rural female heads of households in Ilam? There have been many studies on women's empowerment. In this regard, Zohra (2010) showed that the lack of a male breadwinner and lack of access to the necessary resources leads to the vulnerability of female heads of households in Bangladesh, which in turn harms the socio-psychological status of these women. The results of Javed and Asif's research (2011) showed that female heads of households are more exposed to poverty than male heads because these women need more support. Unemployment is higher among these women; In these families, the tendency to have children is higher than in other families, and in the end, these women have less wealth and income than the male heads.

Wang and Wong (2011) believe that as women become more empowered, their productivity, political participation, and social role increase. This in itself requires raising the level of education and training of women, which is a prerequisite for positively oriented management about education. However, Chiang and Hsieh (2012) have also emphasized the effect of psychological empowerment on employment and have shown in their research that the laws and resources of women's access to socio-economic services are insufficient and make them vulnerable. On the other hand, Chia et al. (2017) in a study entitled "Female Heads of Household and Living Conditions in Latin America" concluded that the number of female heads of households is increasing worldwide and female-headed households are poorer than male-headed households, so policymakers need to provide equal opportunities for women. Findings from research in Iran and other parts of the world show that female heads of households face chronic and persistent pressures and negative social attitudes towards themselves and receive very little social support. Therefore, it is not surprising that they have a high rate of mental disorders. The high rate of psychological problems in them is due to economic and social conditions and is not related to their gender. On the other hand, Ghanbari and Ansari (2014) in a study entitled "Identification and explanation of social and economic factors affecting the empowerment of rural women" concluded that the most important factors affecting the empowerment of rural women, and their participation in economic activities, are individual and social factors. Also, the main obstacles to women's empowerment are factors such as lack of job opportunities, low level of education, family decisions, and lack of legal protections and communication networks.

Given the role and importance of empowerment and its impact on various economic, social, and cultural variables, it is necessary to comprehensively study the research topic. Due to the complexity of this category and its multidimensional nature, designing an appropriate model for empowering female heads of households and influential factors in this category can help us answer questions related to the research topic. Therefore, the purpose of this study is to investigate the factors affecting the employment-oriented empowerment of rural female heads of households in Ilam.

\section{METHODOLOGY}

In terms of monitoring and degree of control, this is field research and in terms of method of obtaining facts and data processing, it is a survey study and in terms of data collection, it is descriptive-correlational. The statistical population of this study is 14156 rural female heads of households in Ilam. The sample size was set for 374 people using Krejcie and Morgan Table. In this study, due to having a list of the names of all women studied, a systematic sampling method was used. The data collection tool in this study was a researcher-made questionnaire that was developed in two parts according to the research objectives and study variables. In the first part, the individual characteristics of the subjects were measured. The second part includes various dimensions of professional competencies and empowerment variables that have been designed and measured in the form of a five-point Likert scale. The content (face) validity of the questionnaire of this research was provided through a panel of experts (professors of the Department of Agricultural Extension and Education of some public and free universities in the country as well as experts on employment-oriented empowerment issues of the Relief Committee and institutions related to 
rural development). The reliability of the questionnaire was also measured through Cronbach's alpha. The results of Cronbach's alpha test (Table 1) show that the alpha level of the research variables is good and acceptable.

Table 1. Cronbach's alpha value of the studied variables

\begin{tabular}{lccc}
\hline & Section or Variable & Number of Items & Cronbach's alpha \\
\hline 1 & The psychological dimension of professional competencies & 19 & 0.82 \\
2 & The political dimension of professional competencies & 15 & 0.78 \\
3 & The social dimension of professional competencies & 15 & 0.85 \\
4 & The economic dimension of professional competencies & 13 & 0.93 \\
5 & The cultural dimension of professional competencies & 12 & 0.88 \\
6 & The technical dimension of professional competencies & 7 & 0.91 \\
7 & The health dimension of professional competencies & 8 & 0.87 \\
8 & Empowerment & 20 & 0.92 \\
\hline
\end{tabular}

In the descriptive statistics section, the frequency distribution table, center orientation, and dispersion indices such as mean, standard deviation, and estimated standard deviation were used. In socio-economic research, the researcher mainly seeks to analyze and explain the data and variables; For this reason, he tries to examine the relations between the variables, the differences between the studied groups or to explain the dependent variable through independent variables, etc., using inferential statistics. In the inferential statistics section of the research, correlation and regression analysis were used. All these analyzes were performed using SPSS v25 statistical software.

\section{RESULTS}

The results showed that the mean age of the subjects was 43.56 years, the oldest of which is 86 years old and the youngest is 21 years old. Also, most of the subjects with a frequency of 102 people $(33.33 \%)$ are in the age group of 31 to 40 years old. According to the research findings, 88 (28.8\%) of the studied people are illiterate and $66(21.6 \%)$ have primary education and a small number of people are in higher education. The results showed that according to the sample selected from the statistical population of the study, 250 people (81.7\%), ie the largest number of people studied, are unemployed. Also, $276(90.2 \%)$ of the subjects are covered by at least one type of support of supporting organizations and $30(9.8 \%)$ are not supported by any organization. The highest percentage and frequency of people participating in the research is from the Imam Relief Committee. According to the sample selected from the statistical population of the study, 100 people (32.7\%) have a high tendency to home activities and 21 people (6.9\%) have a low tendency to home activities.

Table 2. Characteristics of the subjects studied

\begin{tabular}{|c|c|c|}
\hline Variables & Frequency & Mean \\
\hline Age & & 43.56 \\
\hline Aducation level & $\begin{array}{c}88(28.8 \%) \text { illiterate, } 66(21.6 \%) \text { primary education, } 47 \text { diploma, } 50 \\
\text { university education }\end{array}$ & \\
\hline Marital status & $131(42.8 \%)$ widowed, $104(33.98 \%)$ married, 17 (5.55\%) single & \\
\hline Employment status & $250(81.7 \%)$ unemployed & \\
\hline $\begin{array}{l}\text { Coverage status of } \\
\text { supporting } \\
\text { organizations }\end{array}$ & $\begin{array}{l}276(90.2 \%) \text { covered by at least one supporting organizations, } 30(9.8 \%) \\
\text { not covered by any organization, the highest percentage, and frequency is } \\
\text { related to the Imam Relief Committee }\end{array}$ & \\
\hline $\begin{array}{l}\text { The tendency to do } \\
\text { housework }\end{array}$ & $\begin{array}{c}100(32.7 \%) \text { have a great desire for home activities and } 21(6.9 \%) \text { have } \\
\text { little desire for home activity }\end{array}$ & \\
\hline
\end{tabular}




\subsection{Results of Pearson Correlation Analysis}

Since the variables of this study have a normal distribution, so to test the relationship between the research variables, the Pearson correlation coefficient was used, the result of which is presented below.

The results of the correlation coefficient between economic, psychological, political, social, cultural, technical, and health dimensions of professional competence and employment-oriented empowerment showed that there is a significant relationship between these variables at the level of one percent error with 99 percent confidence. Therefore, the research hypotheses that there is a significant relationship between the dimensions of professional competence and employment-based empowerment are confirmed (Table 2). In other words, the dimensions of professional competencies have a positive and significant effect on the employment-oriented empowerment of female heads of households.

Table 3. Correlation results of professional competence dimensions with empowerment based on the Pearson correlation coefficient

\begin{tabular}{cccc}
\hline \multirow{2}{*}{$1^{\text {st }}$ variable } & $\begin{array}{c}2^{\text {nd }} \text { variable (Dimensions of professional } \\
\text { competencies) }\end{array}$ & $\begin{array}{c}\text { Pearson correlation } \\
\text { coefficient }\end{array}$ & $\begin{array}{c}\text { Significance } \\
\text { level }\end{array}$ \\
\hline \multirow{5}{*}{ Empowerment } & Economic & $0.404^{* *}$ & 0.000 \\
& Psychological & $0.601^{* *}$ & 0.000 \\
& Political & $0.406^{* *}$ & 0.000 \\
& Social & $0.616^{* *}$ & 0.000 \\
& Cultural & $0.544^{* *}$ & 0.000 \\
& Technical & $0.441^{* *}$ & 0.000 \\
& Health & $0.501^{* *}$ & 0.000 \\
\hline
\end{tabular}

Significance level: **: Significance at the level of one percent

Source: Research Findings

\subsection{Regression Analysis Results}

In this section, to investigate the effect of independent variables on the dependent variable of the research and considering the validity of different regression methods, simultaneous regression has been used. The purpose of regression is to investigate the effect of independent variables on the dependent variable, predict the changes of the dependent variable and determine the share of each independent variable in explaining the variance of the dependent variable (Kalantari, 2010). For this purpose, all the variables whose correlation with the dependent variable has been proved were included in the regression equation, then the effect of each independent variable on the dependent variable was investigated (Table 3 ). Also, to perform the regression, Gujarati (1995) recommended that the data tolerance level be used to determine the collinearity between the independent variables. The results of the tolerance level of the outputs of this study were calculated to be more than 0.1 , which indicates that there is no collinearity between the independent variables. Also, the value of VIF is a long way from the value of 2, which indicates that there is no collinearity between the independent variables. The results of this analysis showed that the regression equation with $\mathrm{F}=37.987, \mathrm{P}=0.000$ was significant at the level of $1 \%$ error and $99 \%$ confidence. This means that at least one independent variable has affected the dependent variable. Findings indicate that the psychological, social, cultural, and technical dimensions of professional competencies were significant, respectively, with regression line slope $(B=0.178$ and $t=2.741),(B=0.156$ and $\mathrm{t}=0.709),(\mathrm{B}=0.218$ and $\mathrm{t}=2.963)$ and $(\mathrm{B}=0.079$ and $\mathrm{t}=2.512)$ and had the greatest effect on the empowerment of rural women. On the other hand, the results of multiple regression showed that the value of the adjusted coefficient (Adjusted R square) is 0.522 , that is, $52 \%$ of the changes of the dependent variable are explained by the independent variables. Hence, the regression equation obtained from this analysis is as follows: 
$\mathrm{Y}^{\prime}=1.229+0.178 \mathrm{X}_{1}+0.156 \mathrm{X}_{2}+0.218 \mathrm{X}_{3}+0.079 \mathrm{X}_{4}$

$Y^{\prime}=$ Empowerment

$\mathrm{B}=$ constant-coefficient

$\mathrm{X}_{1}=$ Psychological dimension

$\mathrm{X}_{2}=$ Social dimension

$\mathrm{X}_{3}=$ Cultural dimension

$\mathrm{X}_{4}=$ Technical dimension

Table 4. Results of regression analysis of the effect of independent variables on empowerment

\begin{tabular}{|c|c|c|c|c|c|c|c|}
\hline \multirow{2}{*}{ Variable } & \multicolumn{2}{|c|}{ Non-standard coefficients } & \multirow{2}{*}{$\begin{array}{c}\text { Standard coefficients } \\
\text { Beta }\end{array}$} & \multirow{2}{*}{$\mathrm{T}$} & \multirow{2}{*}{ Sig } & \multirow{2}{*}{ Tolerance } & \multirow{2}{*}{ VIF } \\
\hline & B & Std. Error & & & & & \\
\hline Constant & 1.229 & 0.898 & - & 6.211 & 0.000 & - & - \\
\hline Economic & 0.002 & 0.036 & 0.003 & 0.062 & 0.951 & 0.78 & 1.11 \\
\hline Psychological & 0.178 & 0.066 & 0.171 & 2.741 & 0.007 & 0.78 & 1.11 \\
\hline Political & 0.037 & 0.053 & 0.038 & 0.709 & 0.479 & 0.763 & 1.31 \\
\hline Social & 0.156 & 0.052 & 0.189 & 2.963 & 0.003 & 0.78 & 1.35 \\
\hline Cultural & 0.218 & 0.048 & 0.242 & 4.576 & 0.000 & 0.668 & 1.4 \\
\hline Technical & 0.079 & 0.032 & 0.143 & 2.512 & 0.013 & 0.65 & 1.09 \\
\hline Health & 0.037 & 0.037 & 0.055 & 1.010 & 0.313 & 0.85 & 1.46 \\
\hline
\end{tabular}

Source: Research Findings $\quad(\operatorname{Sig}=0.000) \quad \mathrm{F}=37.987 \quad$ ADJUSTED R ${ }^{2}=0.522 \quad \mathrm{R}^{2}=0536 \quad \mathrm{R}=0.732$

Significance level: **: Significance at the level of one percent; *: Significance at the level of five percent

\section{CONCLUSIONS AND SUGGESTIONS}

In recent years, the concept of empowerment has become an integral part of the policies of NGOs and development organizations to support rural and agricultural development and women. Also, one of the most important rural development policies in the present era is the empowerment of rural women. Empowerment is empowering people to help them develop a sense of self-worth and overcome their disabilities. In this study, the factors affecting the employment-oriented empowerment of rural female heads of households in Ilam were investigated. The results of the correlation analysis showed that there is a significant relationship between the economic dimension of professional competencies and empowerment. In other words, the economic dimension of professional competencies has a significant effect on the empowerment of rural women. Since economic factors and having sufficient capital play an effective role in starting any type of business, it can be concluded that in the study area, this factor also has a significant impact on the empowerment of female heads of households. Also, since most rural female heads of households do not have adequate financial resources, the economic factor is one of the most important factors that can be effective in empowering and creating employment for women so that if these people have the adequate financial capacity, they can start a business more easily. The results of the study of Kermani et al. (2013) also confirm this finding. In their study, these researchers concluded that economic factors have a significant impact on the empowerment of rural women. On the other hand, the results of the correlation analysis showed that there is a significant relationship between the political and social dimensions of professional competencies and women's empowerment. In other words, the social and political dimensions of professional competencies have had a positive effect on empowerment. Therefore, it can be concluded that if the social and political conditions are right for women to work in society, they will be able to start a business. Since there are no suitable social and political conditions for women's employment in rural areas, this issue is considered as one of the obstacles to the empowerment of rural women and by improving social and political conditions and supporting women socially and politically, it is possible to act effectively in empowering rural women. Hemmati Vine et al. (2012) also concluded in their study that social and political factors affect women's empowerment, which confirms the 
results of this study. The results of the correlation analysis showed a significant positive relationship between cultural and psychological dimensions of professional competencies and women's empowerment. In other words, the cultural and psychological dimensions of professional competencies have a significant effect on the empowerment of rural women. This finding is consistent with the results of the study of Hemmati Vine et al. (2012). In their study, these researchers concluded that cultural and psychological factors have a significant impact on women's empowerment. Because rural female heads of households in rural areas are under certain cultural conditions and are also psychologically different from other women due to their living conditions, by considering their psychological characteristics and improving the cultural conditions in the village, we can greatly empower and create businesses for them.

On the other hand, the results of examining the correlation coefficient between the technical and health dimensions of the professional competencies with empowerment showed that there is a significant relationship between these two variables. In other words, technical factors have a positive effect on the empowerment of rural female heads of households. Since having technical skills and knowledge is one of the effective factors in empowering women and creating any business, by providing effective training in the field of job creation as well as special training for any type of business, an effective step can be taken to empower the rural women. On the other hand, since the health dimension of professional competence has a positive effect on the empowerment of rural female heads of households and it is one of the basic needs of women, the empowerment of these women can be provided to a large extent by improving the health conditions and paying attention to the health of rural women, especially rural female heads of households.

Finally, the results of regression analysis showed that the psychological, social, cultural, and technical dimensions of professional competencies have the greatest impact on the empowerment of rural women and, in other words, explain $52 \%$ of the variable changes in women's empowerment. These results are consistent with the studies of Kalantari et al. (2010) and Ghanbari and Ansari (2014). In their studies, these researchers concluded that the factors affecting women's empowerment are four components: individual-psychological, economic participation, infrastructure, and social-institutional. In general, the results of the present study showed that in addition to technical and psychological factors, social and cultural factors also have a significant effect on women's empowerment. Therefore, it is suggested that to increase the socio-political participation and social health of female heads of households, government and supportive institutions should take the necessary measures to create a culture, change society's attitude towards the harm of these families, and eliminate their social isolation. In this regard, holding training classes to strengthen life skills, decision making, problem solving and communication, and social skills of female heads of households and increasing levels of political awareness by emphasizing their valuable role in the development and excellence of society can be effective.

\section{REFERENCES}

Boldaji, T., Forouzan, A., \& Rafiee, H. (2011). Quality of life of female heads of households under the auspices of the Welfare Organization and women working in services. Social Welfare Quarterly, 11(40), 9-28.

Liu, C., Esteve, A., \& Treviño, R. (2017). Female-headed households and living conditions in Latin America. World Development, 90, 311-328.

Chiang, C. F., \& Hsieh, T. S. (2012). The impacts of perceived organizational support and psychological empowerment on job performance: The mediating effects of organizational citizenship behavior. International journal of hospitality management, 31(1), 180-190.

Connell, J., Brazier, J., O'Cathain, A., Lloyd-Jones, M., \& Paisley, S. (2012). Quality of life of people with mental health problems: a synthesis of qualitative research. Health and quality of life outcomes, 10(1), 138. 
Eftekhari, N., Payandeh, A., Torabi, F., \& Chegini, T. (2013). Social, economic, and health characteristics of femaleheaded households with emphasis on support policies and programs. Tehran: Research group of technical plans and statistical methods of the Research Institute of Statistics.

Ghanbari, Y., \& Ansari, R. (2014). Identification and explanation of social and economic factors affecting the empowerment of rural women (Case study: Rostam city). Journal of Rural Research and Planning, 4(3), 1-10.

Hemmati Vine, H., Abedi Sarvestani, A., Abdolahzadeh, Gh., \& Mahboubi, M. (2012). Home Employment and Barriers to Women's Business: A Study of Rural Women in Kermanshah. National Conference on Entrepreneurship and Management of Knowledge-Based Businesses.

Javed, Z. H., \& Asif, A. (2011). Female households and poverty: A case study of Faisalabad District. International Journal of peace and development studies, 2(2), 37-44.

Kalantari, Kh., Shabanali Fami, H., \& Soroush Mehr, H. (2010). Investigating the Facilitating and Inhibiting Factors of Empowerment of Rural Women in Isfahan. Rural development, 1(2), 107-124.

Kermani, M., Mazlom Khorasani, M., \& Behravan, H. (2013). Factors Affecting the Empowerment of female Heads of Households Studied: Women Working in Kosar Centers of Tehran Municipality in 2012. Iranian Journal of Sociology, 14(3), 116-148.

Pap zen, A., Khaledi, Kh., \& Soleymani, A, (2011). Evaluation of technical and vocational training of rural women in the field of handicrafts. Women's Sociology Quarterly, 2(3), 21-37.

Wang, J., \& Wong, C. K. (2011). Understanding organizational citizenship behavior from a cultural perspective: An empirical study within the context of hotels in Mainland China. International Journal of Hospitality Management, 30(4), 845-854.

Habib, T. Z. (2010). Socio-psychological status of female heads of households in Rajshahi City, Bangladesh. Antrocom Online Journal of Anthropology, 6(2), 173-186. 